\title{
Does the Fishing Behavior at Global Scale Really Make Food Security Stronger?
}

\author{
Hidalgo Gallardo Amada, Hidalgo Gallardo Ruth Leticia \\ Department of Economic and Management Science, University of Hidalgo State, Pachuca, México \\ Email: misshidalgo2009@yahoo.com.mx, ruth.757@hotmail.com
}

Received 4 February 2016; accepted 12 March 2016; published 15 March 2016

Copyright (C) 2016 by authors and Scientific Research Publishing Inc.

This work is licensed under the Creative Commons Attribution International License (CC BY). http://creativecommons.org/licenses/by/4.0/

(c) (i) Open Access

\begin{abstract}
Due to the accelerated economic liberalization, the environment has been damaged by the high and constant emission of $\mathrm{CO}_{2}$, phenomenon that produces global warming as well as greenhouse effect. These processes have a direct influence in land, water and air; the influence on seas is detected on the natural resource of fish and seafood, which tends to change their geographic status, mutation and extinction of the specie. This article has the purpose to reflect on the importance about the marine natural resources conservation since they are food products with high protein and worldwide consumption rates. Because of this, the present investigation aims to elaborate a descriptive analysis based on the Complex Interdependence Theory in the fishing industry during the period 2006-2013. This analysis has showed that the productivity of the resource presents unbalances in characteristics, regulation, production and trade, for what it is necessary the restructuring of the fisheries sector with reinforced and strict regulation of the activity to face this item delay.
\end{abstract}

\section{Keywords}

Fishery, Environment, Characteristics, Regulation, Production, Commercialization

\section{Introduction}

As results of world imbalances, the Global warming and the Greenhouse effect, the sea contamination's indicates toxic and organic irregularities on the natural resource. This problem refers to a rearrangement in the fishing industry in two guidelines: to attend the mandatory laws and food security. These guidelines and commitments must be assumed by the state with immediate actions to obtain the care of natural resource and avoid the deterioration of the sector.

In the international agenda, the fishing affair is a relevant topic to be agreed; hence it has been subject of accele- 
rated planning and determinations by the International Community (IC), which had always supported agreements towards the environmental improvement, mainly about the mitigation of $\mathrm{CO}_{2}$ emissions. The search of protecting the environment has led to watch the good practices towards the present and future welfare of mankind.

Despite of all agreements created by the IC, the emission rates are still high, since the states still practice the economic liberalization also international trade negotiations. This great economic activity seems to indicate that emissions has passed the indicative of the Kyoto Protocol, a legal base destined to generate strategies for the states and Intergovernmental Organizations (IGO) which in turn take action to control and mitigate $\mathrm{CO}_{2}$ emissions.

Therefore, while the $\mathrm{CO}_{2}$ levels are raising without control, the global warming and the greenhouse effect are still detrimental to the natural resource; the damage is detected in conditions such as the change of the resource of geographical zone searching for its status; because of the toxic environment, it is forced either to death or mutation.

In addition to these resource's conditions, other important factors are detected, such as the sea over-exploitation, without regarding close seasons, capture of new species, as well as the sea contamination due to obsolete infrastructure fisheries industry.

All of these circumstances that sea resource is facing are favorable to reflect on the inconveniences that the international society will have to overcome in a near future regarding to the security of the fishing industry. Therefore, it is necessary to analyze the fishery worldwide, such as, characteristics, regulation, productivity and commercialization.

\section{Methodology}

This researching has been made on a method descriptive-analytic, based on the Interdependence Complex Theory by Keohane and Joseph Nye (1977) [1], they analyses results about international economical acceleration and the damaged to the atmosphere caused inclusive his impact in: human, natural resource and environmental, which they called a complex interdependence.

This deterioration has led to climate change and greenhouse; disadvantages that affect fishing, in its aspects such as production, demand and marketing, this situation placed in a vulnerable sector to ensure food security.

To perform this analysis, have been considered documents and literature from rules of the DIP, the Sea Law and Environmental Law until information form ministerial meetings, led by the UN, such as the Earth Summit in Rio de Janeiro [2], the United Nations Framework Convention for Climate Change (UNFCCC) and Kyoto Protocol as regulatory bases. Also the support of the United Nations Environment Program (UNEP), Organization for Economic Co-operation and Development (OECD), World Health Organization (WHO). Likewise, is analyzed information of the United Nations Organization for food and Agriculture (FAO) with the most green cities programs and safeguard resources also UNESCO with its water, environment and sanitation program.

Also is taking into account, data from Intergovernmental Group of experts on changing climate (IPCC) and Committee for Fisheries (COFI) instances that contribute with tracking, application of tests, opinions, and advances in the regulation of the States, which bring about environment and sustainable development scheme. At same time, it is considered literature from authors involved in the topic.

Whereas this frame of reference, is to carry out a full analysis to see if determinations of the IC with respect to fishing will be aimed at its regulation, monitoring and global food security.

\subsection{The Fishing Behavior at Global Scale: Regulations, Characteristics, Productivity and Trade}

The production, industrialization, liberalization and modernization have influenced in the existing changes in the marine ecosystems. It is important to restructure the fishing industry in order to provide food security also to elaborate economic growth projections to protect the resource for future generations. This dissertation implies to analyze the different sector processes taking into account: current conditions, behavior, production, supply and demand, liberalization and regulation of the product, all this aspects to be considered when setting global projections.

Likewise, in this research, is confronted current population versus the annual per capita consumption thus, we will be able to know if there is a reliability and coverage of the fishing industry, in a scenario of productivity. In consequence, as commented before, the productive processes are feeble, due to climate change and factors such as port infrastructure making an influence on the security of the sector. These approaches are examined below. 


\subsection{Fishing Characteristics}

The importance of the marine resources like the fish and the seafood, resides in their nutritional baseline for the human being, therefore it is imminent to study their behavior of the last 50 years. Similarly considering that the climate change has had an impact on the sea due to fishing, mostly since the XXI ${ }^{\text {th }}$ century, when an intensification of the restructuration, and care has been made, optimizing their use and distribution.

The World Health Organization [3], in their Millennium Ecosystem Assessment (MEA), reflects about the history of mankind determining that, the last 50 years are the most relevant in ecosystem change, because of the population increase, food consumption per habitant, water, wood, fiber, combustible as well as the changes per economic development and welfare. These processes and advances have had a high cost since the ecosystem has degenerated, the climate risk and poverty [4].

The European Environment Agency [5] refers that fishing largely depends on the health of the marine ecosystems, which also have a crucial role on the fight against climate change, in a way that the changes and the resource depuration are reinforced, bringing a catastrophic effect for mankind including the oceans.

On the other hand, Salinger, (2014) [6] indicates that, the climate change of the XXI ${ }^{\text {th }}$ century makes its effect on two events: moving towards the poles and also the oceans acidification. These effects had led to its reduction, redistribution of the global sea biodiversity, especially of the marine species in sensible regions. This action makes a challenge on the fishing productivity and other natural resources since the species tends to move geographically, searching for its habitat. This fact has occasioned their dead or extinction, in addition to increase difficulty of their capture, reasons which make necessary the use fish optimization for the demand's satisfaction.

The Food and Agriculture Organization of the United Nations [7] indicates that the environmental problems had acquired more importance, due to challenges in the coastal area where conflicts are produced by fishing grounds. However, the biggest damage relies on fishing, especially on the traditional way, practiced in developing countries (DC).

On the other hand, related to the benefits, according to Costello, (2012) [8] confirms that mostly derivate from fishing and seafood protein contribution, their consumption is high besides projecting a continuous growth. Taking into account, the characteristics of fishing and seafood are important not only for human, but for animal feeding, therefore are necessary to point out the sea capacities to satisfy all the demand.

Faced with these problems, the FAO [9] provides researches declaring that fish by-product can also be served as protein for the human being. For example, heads, viscera and bones which contains a high level of essential fatty acid, vitamins and minerals. This FAO's consideration must be taken into account in the resource's reduction, since they can substitute the lack of DC micronutrients.

According to Costello, (2012) [8], the product's is allocated in for important aspects: artisanal fishing, transformation, flour and oil from the fish and aquaculture. Also, it indicates the actions implied by the fishing, such as, production and supply, net and factory equipment, processing and equipment, ice, vessel construction and maintenance, packing, commercialization, distribution, research and administration.

It should be noted the relevance of the product processing, in the area of flour transformation and fish oil used for aquaculture and livestock, whereas by-products may rise on the area of aquaculture, for example the quantity of the whole fish, directly used for human consumption.

Therefore, it is relevant that fish and seafood is $100 \%$ useful, their proteins are basic for the human being, also in the aquaculture new food chain. It is also important to recognize that nowadays, the most popular human nutritional intake is fish, because their high content in omega 3 besides being a low-fat meat, making the fish and seafood high consumption elements and replacing the consumption of red meat.

Consequently, the potential found on fish and seafood such as their vulnerability on the climate change makes imminent the protection of the resource through mechanisms that regulate the sector in areas such as coastlines, capture, processing and commercialization.

The relevant increase of the sector, increasing production demand, shortage for pollution and climate change, attribute more detailed and strictly controlled international law, which guarantees the performance withal the long-term continuity of the developmental measures and resources to sustain them.

\subsection{Global Regulation of Fishing}

The need of the ecosystem preservation, the guideline spreads towards the regulation itself. For this purpose, the IGO have done actions among member states. Through the following section, the actions from the United Na- 
tions (UN) concerned in the Law of the Sea, its code of conduct, the FAO, the World Trade Organization (WTO) and the WHO, as well as the support from other Non-Governmental Organizations (NGO) as the Marine Stewardship Council (MSC) are observed.

Despite the regulation and the trading activity at the international level, the magnitude of the climate change and the pressure from the economic sectorial interests leads to consider the results as insufficient. In consequence, there is an increase of the discussion meetings about the problematic while the resource is diminished.

The [10], in their perspective with the aim of rescue and reorganize the fishing industry, mainly foothold in the Law of the Sea (DM 1982), proposes and disseminates through multilateral conferences between IGO-NGO, a platform of cooperation for the search of more alternatives for the recovery of the ecosystem ${ }^{1}$.

As an adjacent to the Law of the Sea, the UN re-confirms the international actions such as; the Stockholm Declarations and the Earth Summit, in which is re-confirmed 27 principles; specifically the $7^{\text {th }}$ and $11^{\text {th }}$ that approach the ecosystem's integrity topic.

Likewise, the FAO joins the actions through the Committee of Fisheries (COFI) ${ }^{2}$ as a subsidiary body, from which various international forums and world conferences ${ }^{3}$ have emanated and where issues such as: the security of the natural resource, sustainable exploitation of aquatic alive resource, organization and fishing development, subsidies limitation, the responsible seabird, turtles and pelagic capture of tuna, also illegal fishing are promoted $^{4}$.

In addition, the [11] collaterally related to the mentioned regulation, creates the International Code of Fishing Conduct, an international mandatory law, aimed to the preservation, organization and development of all the fisheries, that defines the procedures of capture, processing, commercialization, production and research of both fishing and aquaculture. Guidelines that [2] in their Agenda 21, emphasizes on their exploitation, use and sustainable development.

In the same vein, another IGO joins in action, which is related to the environmental pollution, the WTO. This organization creates the Committee on Trade and Environment ${ }^{5}$, with the purpose of managing the labeling, packed and freight techniques regulations, as well as rules of origin [11]. Also, the WOT creates the Global Forums of Environment Ministers (GMEF), with the aim to reinforce the global environmental governance ${ }^{6}$.

Likewise, with the purpose of encouraging the actions, another IGO is incorporated to this mission; the WHO which in turn takes part in the sustainable development, emphasizing fishery as one of the most important points in their agenda, with the commitment of restoring by 2015 the depleted reservoirs, starting from the recognition the oceans as essential ecosystems besides as a primary source of food, especially for poor countries [3].

In the same way NGO are strongly involved, dealing with the fishing problematic, trying to provide measurement, experience and mechanisms that may facilitate the activity and protect the natural resource, as is the case of Marine Stewardship Council (MSC) ${ }^{7}$.

${ }^{1}$ UN: United Nations Convention on the Law of the Sea.-Based on previous conferences of the Geneva sea 1958 and 1960 , derived from the changes and terms of sea freedom as well as the search of a new sea reorganization where the States receive benefits in their national and international waters.

${ }^{2}$ FAO: Formally created since 1965 from the Committee on Fisheries dependent on the FAO-UN to support the topics on aquaculture and fishing, generating bonds between the states, organization and fishers regarding the regulation and the problem on fishing activity.

${ }^{3}$ FAO: Committee for Fisheries and COFI's conferences. Roman agreements (1984 and 1991). FAO agreement of the 1993 compliance; a decade of change, Rome (1994), UN agreement of fishes' population in 1995; International code of conduct for responsible fishing (1995); International plan of action for reorganizing the fishing capacity, Rome (1999); Reykiavic Conference about responsible fishing in the marine ecosystem (2001).

${ }^{4}$ International Fishers Forums: The forums to debate relevant aspects of fishery had took place since 2000 and the following countries were their based in are: New Zealand (2000), Hawaii (2002), Japan (2005), Costa Rica (2007), London (2011).

${ }^{5}$ Committee on Trade and Environment: Created in 1994 and with a work plan from the commerce and the ecosystem in general, the liberalization, and the commerce obstacles; taxes, services and intellectual property, as well as relations with organizations dealing with the environment. This Committee celebrates in extraordinary meetings and effects the revisions of acts created in the reunions of OECD in many different Doha gatherings. To observe the dynamic and operability of such revisions as in the documents, read

https://docs.wto.org/dol2fe/Pages/FE_Search/FE_S_S006.aspx?Query=(\%20@Symbol=\%20tn/te/inf/4*\%20)\&Language=SPANISH\&Cont ext=FomerScriptedSearch\&languageUIChanged=true\#.

${ }^{6}$ UNEP International forums by ministers of the Environment-Based on the Estocolmo Conference and determine for the council of UN as a base to the States show strategies, statistics, strong analysis about the sea and its natural product, using the technology and the intellect as a tool in consequence the Developing countries can mitigate, ask for financial resources and involve the society in this job to keep the environment safe. The first conference is done in Sweden in 2000, according to the $21^{\text {st }}$ agenda and the Doha meetings.

${ }^{7}$ Marine Stewardship Council (MSC): A non-governmental organization dedicated to promote the fishmongers' certification, traceability and an eco-label for all sustainable fishing products of capture. A world organization working directly with fishmongers, fish products companies, scientists, and others. Supports in topics such as labeling, packing, prices, fairs, offers, fishing business directory, statistics and other aspects related to certified sustainable fishing and aquaculture. 
Inside the ecosystem problematic and its degradation, it can be visualized the inclusion and use of various IGO, NGO, States and other authorities to meet in several international conferences, in which possibilities of taking care of the ecosystem may arise. Several programs, projects and actions had been generated, all based on the international regulation with the intention of producing results; but these are attended slow or very poor, since the restructuration not only depend of the regulations, but on the international interest and other topics related with fishery.

The debate on international forums and the rate of creation of new instances are still growing, along with the climate change. However, the specie presents low-productivity actions and geographical dispersion, seeming that might not be solved in a short-term.

According to Love, (2010) [12], the fishing internationalization presents a relation to the growth of the product demand, to the nutritional ingestion in human health and to the reproduction of the recourse, which calls into question the sustainability of fishing production.

\subsection{Fishing Production at Global Scale}

The fishing production depends on how atmospheric climatic conditions are reflected on the seas, in the IC sustainable activities practices and the responsible fisheries management. The Developing countries are the ones that present higher fishing production but at the same time they depend on the developed ones to carry out this activity.

According to the FAO [13] indicators, the DC are an important part in the supply of this product in global markets, above farming products such as rice, meat, milk, sugar, and banana where the industrialization and modernization of the production reduce the dependence of industrialized countries regard to DC.

These parameters suggest visualizing the fishing sector in their worldwide production, in this case considering the 2011 year. Table 1 indicates that the main producers are China, Peru, Indonesia, USA and India.

In addition to these data from producers and fishing fleets, it is necessary to know the behavior of the worldwide production, detailed in Table 2 with an established period of 8 years, in order to observe the variation between production and consumption. According to the table, if it is just considered the 2008 to 2013 capture, significant falling indicatives are observed, but the aquaculture production could complement the indicative in order to be able to supply the consumption, since during these years is experienced the increase of the aquaculture production, therefore the importance of aquaculture in the sector can be confirmed, without this practice, the consumption would not be covered.

Relating the above data with the population growth rates of the World Bank [14], the per capita average consumption is about $19 \mathrm{kgs}$ established in 2011, then: the population in 2012 of $7057 \mathrm{~m} /$ inhabitants consumed $134.0 \mathrm{~m} / \mathrm{t}$ of fish while the capture was only of $91.3 \mathrm{~m} / \mathrm{t}$. The exercise is similar for 2013, the population of 7200 $\mathrm{m} / \mathrm{inh}$ abitants consumed $136.8 \mathrm{~m} / \mathrm{t}$ and the capture was only of $92.6 \mathrm{~m} / \mathrm{t}$. This correlation of data indicate us that capture is still low for what it is necessary the aquaculture production to be able to supply the fish worldwide consumption.

In another perspective, the FAO notes that a considerable part of the fish consumed in developed countries comes from importations, due to the constant demand and to the national fishing production decrease (10\% less in the 2000-2010 period) it is anticipated that the importation's dependence, particularly from the developed countries, will increase in the next years.

Therefore, it is strongly necessary to consider the complexity of interactions among productivity, climate change and ecosystem. From which exist variations during the seven years indicated, that are largely due to the resource gap. This allows increasing efforts for the effective sector's reconstruction [15].

The recommendations showed by the [16] are still carrying out around the sustainable fishing, regulations, as well as measures of the sea's management, fishing organization through licenses, especially in the fishing impacts related to environment. In this regard, [17] indicate that the $75 \%$ of the fishing-ground fish has been declared exploited or overexploited, for what the organism concludes the need to reinforce the prompt observation in the maxim potential capture from the oceans.

According to the evaluation of vulnerability done by the Intergovernmental Panel on Climate Change [18], consider that the ecologic systems are intrinsically dynamic, constantly influenced by the climate variability. The influence of mutability on climate largely depends of the magnitude which the medium and extreme weather change, since it is expected that climate change is faster than the adaptation process and the ecosystem reset- 
Table 1. Production, producers and fishing fleets at global scale.

\begin{tabular}{|cl} 
Fishing production (in million tons) $\mathbf{2 0 1 1}$ & $\begin{array}{l}\text { 156.2 Considering the fish, crustacean, mollusk species and some others sea-animals. } \\
\text { For } 3^{\text {rd }} \text { consecutive year they have increased and in } 2011 \text { they excided the } 74 \text { millions of } \\
\text { tons, impossible to be accomplished since } 2001 .\end{array}$ \\
\hline $\begin{array}{c}\text { Aquaculture fishing production } \\
\text { (in millions tons) } 2011\end{array}$ & $\begin{array}{l}62.7 \text { with a value of } 130.2 \text { billion dollars (58\% more than 2001) } \\
\text { In } 2001 \text { reported a production of } 36.6\end{array}$ \\
& China \\
Pain fishing countries & Indonesia \\
& USA \\
& India \\
& Anchoveta \\
& Pollock \\
Skipjack tuna & Atlantic herrin \\
Pacific mackerel & Codling \\
Tunas \\
Prawns \\
Cephalopods \\
\hline
\end{tabular}

\begin{tabular}{cl}
\hline & China 38.6 \\
& India 4.6 \\
& Vietnam 2.8 \\
& Indonesia 2.7 \\
Main aquaculture producers & Bangladesh 1.5 \\
(in millions tons) & Norway 1.1 \\
& Thailand 1.0 \\
& Egypt 986,800 \\
& Chile 964,800 \\
& Myanmar 816,800 \\
& They represented the $88 \%$ from the total value of the worldwide production. \\
\hline Fishing fleets (millions embarkations) & 4.4 steady figure since 1998 (Asia has the $73 \%$, after Africa, AL, Caribbean, EUA, and \\
& EU) \\
& $3.2 \%$ operate in marine waters \\
& Globally, the $60 \%$ of the embarkations operate with motor, of which $85 \%$ measure 12 \\
& meters in length. \\
\hline
\end{tabular}

Source: Own creation based in FAO’s information denominated “Overview: Fishing production, trends and principal questions”.

Table 2. Fishing production from 2006 to 2013 (Millions tons).

\begin{tabular}{|c|c|c|c|c|c|c|c|c|}
\hline Catch & 2006 & 2007 & 2008 & 2009 & 2010 & 2011 & 2012 & 2013 \\
\hline \multicolumn{9}{|l|}{ Fishing } \\
\hline Continental & 9.8 & 10.0 & 10.2 & 10.4 & 11.2 & 11.5 & 11.6 & 11.7 \\
\hline Maritime & 80.2 & 80.4 & 79.5 & 79.2 & 77.4 & 78.9 & 79.7 & 80.9 \\
\hline Total Fishing & 90.0 & 90.3 & 89.7 & 89.6 & 88.6 & 90.4 & 91.3 & 92.6 \\
\hline \multicolumn{9}{|l|}{ Aquaculture } \\
\hline Continental & 31.3 & 33.4 & 36.0 & 38.1 & 41.7 & 44.3 & 66.5 & 44.7 \\
\hline Maritime & 16.0 & 16.6 & 16.9 & 17.6 & 18.1 & 19.3 & 23.8 & 52.4 \\
\hline Total Aquaculture & 47.3 & 49.9 & 52.9 & 55.7 & 59.9 & 63.6 & 90.3 & 97.1 \\
\hline Worldwide production & 47.3 & 140.2 & 142.6 & 145.3 & 148.5 & 154.0 & 181.6 & 189.7 \\
\hline Human Consumption & 114.3 & 117.3 & 119.7 & 123.6 & 128.3 & 130.8 & No data & No data \\
\hline
\end{tabular}

Source: Own creation based on FAO “World state of fisheries and aquaculture 2012” statistic data 2012 and 2013 ;

Note: sea vegetables are not considered. The final numbers might not match due to the rounding. The figures for 2011, 2012, and 2013 are provisional calculations taken from FAO. 
tlement. Regard to this process, then is considered that the direct effects of major concentration of $\mathrm{CO}_{2}$ in the atmosphere can increment the damages on productivity and the efficiency of the water use in some vegetable species.

In sum, the statistic data of fishing production in the 7 years presented indicate a continue productivity reduction from 2008 to 2010 besides the FAO's reports which indicate that the $75 \%$ of the seas are overexploited. This information details the seriousness of the marine specie to the food crisis that can be presented in the short term.

On the other hand, the investigations about the fishing problematic put over all that the sustainability proposal implies to balance the supply and demand with the environment through a responsible management that also allows the fishers to contribute to the economic and social development of the communities that depends from this industry. The supply and demand are determinants in the commercial transactions; which for the great powers are traduced in negotiate to obtain the product that implies also take care and make an environmental responsible management.

There is not another option that; adjusts the demand to an offer that avoids the complete draining, allows the adaptation of the seas to the climate changes and be necessarily less; this implies important changes in the world trade.

\subsection{Global fishing Commercialization}

The population's demand generates the resources exploitation; and then seas are devastated. The goal is to obtain natural resource and to secure the dietary nutrients, likewise it is established the complete use of the product, that is, from all the resource's parts that according to Scientifics, are consumable.

Through this determination the product demand can be solved as well as increase the supply rates and complementing the international commercialization, spaces where producer countries supply markets, the consume and the species variety on sale.

According to Lem, (2014) [19] the global fishing commercialization generates increasing richness, since the $37 \%$ of the production is internationalized. This converts it in one of the industries, within the food sector, more completely dynamic and globalized. This situation can be confirmed with the figures given in Table 3 respect to the product use, the $85 \%$ is designated to human consume and the other $15 \%$ to flour fabrication and fish oil.

\begin{tabular}{|c|c|}
\hline Use & $\begin{array}{l}85 \% \text { human consumption }(132.3 \mathrm{~m} / \mathrm{t}) \\
15 \%(23.9 \mathrm{~m} / \mathrm{t}) \text { flours fabrications and fish oil } \\
46 \% \text { of human consumption was alive and fresh fish. }\end{array}$ \\
\hline Trade & $\begin{array}{l}2011 \text { Exportations (equivalent in alive weight) } \\
38 \% \text { = } 129595 \text { million dollars (17.1 more than 2010) } \\
2011 \text { Importations (equivalent in alive weight) } \\
\text { 129, } 805 \text { million dollars (16.8\% from } 2010)\end{array}$ \\
\hline Main importing countries (2011) & $\begin{array}{l}74 \% \text { in value of developed countries } \\
\text { USA and Japan } 27 \% \\
\text { EU } 38 \% \text { (if interregional trade is excluded then decreases to } 25 \% \text {, even then the EU is the } \\
\text { world's larger importer) }\end{array}$ \\
\hline Main exporting countries & $\begin{array}{l}\text { China, Norway, Thailand and Vietnam } \\
\text { The developing countries represent an important role due to the ten main countries get } 76 \% \text { of } \\
\text { value. }\end{array}$ \\
\hline $\begin{array}{l}\text { Developing countries and Fishing } \\
\text { trade }\end{array}$ & $\begin{array}{l}\text { It represented the } 53 \% \text { respect to the value and } 60 \% \text { in terms of quantity. } \\
\text { Net exports without considering importations increased to } 34,500 \text { million dollars in } 2011\end{array}$ \\
\hline $\begin{array}{l}\text { Main products traded } \\
\text { internationally }\end{array}$ & $\begin{array}{l}\text { Shrimp: } 15 \% \text { in value terms } \\
\text { Salmon and trout: } 14 \% \\
\text { Bottom species } 9 \% \text { (Hake, coddfish, haddock, and Alaska Pollock) } \\
\text { Tuna: } 8 \% \\
\text { Fish flour: } 3 \% \\
\text { Fish oil: } 1 \%\end{array}$ \\
\hline Consumption and feeding & $\begin{array}{l}2010=18.9 \text { kgs per capita } \\
2011=\text { up to } 19 \text { kgs per capita }\end{array}$ \\
\hline
\end{tabular}

Source: Own creation based on FAO’s information named “Overview: trends and main issues—fishing production”. 
The countries that commercialize the product are headed by China, followed by Norway, Thailand and Vietnam. At this point the developing countries play a very important role, since their exports totalize the $60 \%$ which corresponding 34,500 million dollars. The global per capita consume was of $18.9 \mathrm{~kg}$ in 2010 and $19 \mathrm{~kg}$ in 2011, which give us the human consumption increase.

According to the COFI [13] informs, it is detected an increase of tension on the resources capture, which provoke the intensifying international cooperation reaction, efforts in the application and the access to the code of conduct. The Code covers, in other aspects, the trade on some threatened species, the oceans' governance as well as the aquaculture development in developing countries, as channels to increment the global productivity, which in turn serves to complete the commercial demand.

The commercialization has been benefited by technological progress, achieving the fish capture increase as well as the floating factories automation; nevertheless, there are negative effects due to the provoked pollution by the establishment of vessels on sea for a long period of time. This point has bring it up for debate, giving the opportunity to fisheries, engineers, researchers and governmental officials to know and interchange information about mitigation measures to protect fishery and control this way of commercialization (Baird, 2001) [20].

Currently, fishery internationalization has been so spread that, in markets, a variety of exposed species can be found in common places to sale, because of that, the OECD confirms that fishery is a strong globalized activity. In a way that, the fish from one place of the world is sent to another for processing, arriving to the consumer in a third region, in consequence the key of trade is still product-process-sale-consumer [21].

In this regard, Parks, (2002) [22] comments that such aspects as; liberalization, globalization, the constant south demographic increase and the intensive consumption from North, encourage the increment of fishing activities around the world and its impact on marine resource. In the same direction, Deyra, (2012) [23] argues that the anticipated exploitation of natural resources is being devastated for the reserves rebuilding, so it is necessary the corresponding instances regulation for the oceans protection.

Therefore and according to the above mentioned, it is considered that; the higher consumption the higher trade, practice that it is reflected on the degradation increase as well as on shortage species. This procedure leads the industry to agreed the completely use of fish in order to guarantee; production, transformation and trade to achieve the fishing food security.

\section{Discussion}

In accordance with all this approach, it finds that industrialization, as well as accelerated and overwhelming trade of marine products, force to take protection measures with urgency and thus also of this resources management, in order to allow the markets supply, at the same time visualize the population demand in long term. In this regard, it should be noted that the offer is still controlled by the developed countries since they are the main producers, therefore it will be necessary to immediately attend their priorities since the imbalance between offer and demand generate trade instability, medium to cover global needs.

The four developed topics show the interdependence conditions in the fishing and aquaculture activities, which are fundamental for the IC in two main points: Food security and economic growth. Through the analyzed concepts, it can be confirmed that the resources productivity presents imbalance mostly on: characteristics, consumption and trade, in consequence, a stronger and strict regulation of the activity are the way to face the fishing imbalance.

In addition to an efficient regulation, there are other options to confront the imbalance fishing as: researches that propose to take advantage of all the fish, by the protein wealth represented by the sub products, which before were discarded. Another alternative is to reinforce the aquaculture use, important element to reach the required quantities for human consumption. Although it has been confirmed that aquaculture is an exception in fisheries demand, it is still a momentary impact, it cannot be suggested as a fishing replacement and put it as a resource basis.

In view of the currently problematic and the OECD's scenarios toward 2030, it is presented a dilemma; if a strategy of the industry's better management is not found as well as the establishment of mechanisms to the environmental improves, it is probably that the resources will suffer a significant decrease. Therefore, the States commitment is in environmental care, governance, sustainable development, more successful and efficient natural resources managements.

Therefore, it is important to consider States must comply with effective regulatory guidelines and respect 
them, have a responsible behavior in captures, respect the ban and avoid over exploitation. These guidelines can, in medium term, face fishing imbalances and ensure food security.

\section{Conclusions}

Definitely, policies and practices to address the environmental issues and the restructuring fishing are not considered equitably for developed and less developed countries; because of this, there is a delay on the application of international regulations.

At the same time, the population growth forces to search other alternatives for the fishing resource provision, in such case, aquaculture is the opportunity to be implemented on the domestic policies of States.

This study demonstrates that the worldwide high rates of consumption and low rates of production locate the IC on a defense and permanent complex interdependence of natural resources.

\section{References}

[1] Keohane, R. and Nye, J. (1977) Power and Interdependence: World politics in Transition. Little Brown.

[2] UN (1992) Program 21 Declaration of Rio about Environment and Development. Section I. Social and Economical Dimensions, International Cooperation to Accelerate Sustainable Development of Developing Countries and Connected Domestic Policies. http://www.un.org/spanish/esa/sustdev/agenda21/agenda21spchapter2.htm

[3] WHO (2013) Millennium Ecosystems Evaluation. World Health Organization WHO, Climate Change and Human Health. http://www.who.int/globalchange/ecosystems/mill_assess/es/

[4] UN (2010) UNEP "Marine and Coastal Ecosystem-Based Management: An Introductory Guide to Managing Oceans and Coasts Better”. 12 Global Meeting of the Regional Seas Convention and Action Plans, Bergen, 34.

[5] EEA (2010) The Marine Environment: Pressures on Marine Biodiversity. Biodiversity Fishing. http://www.eea.europa.eu/es/articles/el-medio-marino

[6] Salinger, J. (2014) Food Security in a Warmer World: Wheat, Viticulture, Livestock and Fisheries. ONU-PNUMA, International Conference on Promoting Weather and Climate, Information for Agriculture and Food Security, Atalya, 7-9 April 2014, 1-31.

[7] FAO (1992) The Maritime Fisheries and the Law of the Sea: A Decade of Change. FAO No. 853, 12.

[8] Costello, C., et al. (2012) The Economic Value of Rebuilding Fisheries. OECD Food, Agriculture and Fisheries Papers, No. 55, OECD Publishing, Paris, pp.1-69. http://dx.doi.org/10.1787/5k9bfqnmptd2-en

[9] FAO (1989) Nutrition and Feeding of Cultivated Fish and Schrimps-Training Manual. Project Aquila II-FAO-Italia Field Document No. 4 to Support Latin-American Countries, Brazil. http://www.fao.org/docrep/field/003/ab492s/AB492S00.htm\#TOC

[10] UN (1982) United Nation’s Convention about the Sea’s Law. Based on Previous Sea Conferences of Geneva 1958 and 1960.

[11] FAO (1995) Trade and Marketing of Forest Products. The OMS’ Trade and Environmental Committee. http://www.fao.org/docrep/v7850s/V7850s03a.htm

[12] Love, P. (2010) Fisheries While Stocks Last? OECD. Insights, Organization for Economic Cooperation and Development, Paris, 1-152.

[13] FAO (2011) Global Fishing Rates. General Perspective: Trends and Principal Issues: Aquaculture and Fishing Statistics 2011. FAO Year Book 2011, 6-9. ftp://ftp.fao.org/fi/stat/summary/YB_Overview.pdf

[14] World Bank (2014) Statistical Data of Global Population Growth, Taking into Account the Years 2012 and 2013 with the Purpose to Reflect the Consumption Increase of Natural Fishing Resource. http://datos.bancomundial.org/indicador/SP.POP.GROW

[15] OECD (2012) Rebuilding Fisheries. Inventory of National and Regional Approaches to Fisheries Rebuilding Programmers, 5.

[16] FAO (2013) Regional Commission for Fisheries (RECOFI). 7th Meeting of the Working Groups on Fisheries Management, Kuwait, 5-7 November 2013, Main Outcomes of the Seventh Session of RECOFI and Implications for the WGFM. ftp://ftp.fao.org/FI/DOCUMENT/RNE/RECOFI_2013_WG-FM/default.htm

[17] FAO (2012) Inform of the 30 Period of Sessions of the Fishing Committee. Inform No. 1012, Rome. http://www.fao.org/docrep/017/i3105s/i3105s00.htm

[18] IPCC (1997) Regional Impacts of Climate Change: Vulnerability Evaluation. Intergovernmental Group of Experts on Climate Change, Summary for Policy Responsible, Special Inform of the II IPCC's Work Group, November 1997, 
$1-27$.

[19] Lem, A. (2014) Fish Global Trade Points toward New Records. FAO, United Nation’s Food and Agriculture Organization, Bergen-Rome. http://www.fao.org/news/story/en/item/214442/icode/

[20] Baird, S.J. (Comp. \& Ed.) (2001) Report on the International Fishers’ Forum of Solving the Incidental Capture of Seabirds in Longline Fisheries. Auckland, 6-9 November 2000. Department of Conservation, Wellington, 63 p.

[21] OCDE (2008) Environmental Outlook to 2030. 1-15.

http://www.oecd.org/environment/indicators-modelling-outlooks/40200582.pdf

[22] Parks, N. (2002) The Second International Fishers Forum. Hawaii Convention Center, Honolulu, 19-22 November 2002. http://www.magrama.gob.es/es/pesca/temas/proteccion-recursos-pesqueros/IFF2_Proceedings_tcm7-7350.pdf

[23] Deyra, M. (2012) Droit International Public. Vol. 1, Gualino-Lextensoéd, París, 1-233. 